Secretary. In July, 1898, he was transferred to fresh duties as Registrar and Superintendent of Records, a post which he held until his retirement in October, 1907, after a service of forty-eight years. In the following January he was promoted to K.C.I.E. Not long after his retirement he had the misfortune to lose the sight of one eye; and thenceforward his energies were confined to the locality of his home at Walmer, where for many years he served as a Justice of the Peace and Vice-Chairman of the Wingham Petty Sessional Division. His popularity in the neighbourhood was well attested by the large gathering at his funeral, which took place on the Saturday following his death. W. F.

\title{
Mrs. Haynes Bode
}

Mabel Kate Haynes Bode was the younger daughter of Robert William Haynes, the well-known law publisher. From him she inherited her love of literature and scholarship, as well as the beautiful voice and enunciation which all who heard her lecture will remember.

She was educated at Notting Hill High School, and always showed a remarkable gift for languages. Later, at the suggestion of Professor Rhys Davids, to whom so many of us owe gratitude, she devoted herself, under his teaching and guidance, to Pali. Her Ph.D. was taken, "summa cum laude," in 1898 at Berne, where she worked with Professor Miller-Hess. In 1904 she studied Sanskrit at Pisa with Professur C. Formichi, who speaks of her "as one of the cleverest and best women I ever met".

But it was at Paris that she found the great intellectual influence of her life in the teaching of M. Sylvain Lévi, and in the unity of spirit, under his inspiration, of a band of scholars joined in loyalty of work, love of truth, and disinterested comradeship. She always spoke of that time as the happiest in her life. French became, as one of her French friends said, "her other language." In 1909 she became Assistant Lecturer, and from 1911 to 1917 Lecturer, at 
University College, London, and she was the first Lecturer in Pali at the School of Oriental Studies. Besides her formal lectures, she gave other public ones on Buddhism, and on these she bestowed great care. Among her private pupils was the composer, Gustav Holst, who shows her influence by his setting of Vedic subjects. During the war she was a valued helper to the Belgian Committee and to many exiled scholars; and she worked hard for the French Red Cross and kindred objects. Her last two years were spent in the country, and finally, till her death after a few days' illness from influenza, on 20th January, at Shaftesbury, where she won the hearts of thase who could not share her interests but felt her charm.

Her first work was a paper on Women Leaders of the Buddhist Reformation (Oriental Congress, 1892), and was followed by an edition of the Sāsana Vamısa (1897); "On German Universities" (a pamphlet, 1905) ; The Pali Literature of Burma (1909, R.A.S. Prize Publication Fund); Indices to (a) the Gandhavarnsa (P.T.S., 1896), (b) Pali words discussed in translations (P.T.S., 1901), (c) Śikşa samuccaya (18971902). She collaborated with Professor Geiger in the translation of the Mahāvamsa (1912), and with Mr. T. W. Rolleston in Oriental articles in the Times Literary Supplement, and she wrote many notices of books in the JRAS., including her last article in the January number on the Atthasalini. The work that always occupied her, and that she was happily able to complete, was her section of the Pali Dictionary; and this was a great achievement for one who was never physically strong and who never refused any claim either of friendship or kindness. She had a rare unselfishness ; a deep love of truth ; absolute fairness ; reverence for all sincere thought and belief ; and her work is marked by careful accuracy and delicate perception, and a beauty of style arising from these. In all she said or did "there shone forth" (to quote her own words ${ }^{1}$ of a fifteenth century Burmese commentator) "the scholar's clear and simple soul".

C. Mary Ridding.

1 Pali Literature of Burma, p. 42. 